\title{
Simulasi Metode Statistik untuk Seleksi Single Nucleotide Polymorphism
}

\author{
Mohamad Ikhsan Nurulloh ${ }^{1)}$, Hidayat Trimarsanto ${ }^{2)}$, Yustinus Ulung Anggraito ${ }^{1)}$, Endah Peniati ${ }^{1)}$, R $^{1}$ \\ Susanti ${ }^{1)}$ \\ ${ }^{1)}$ Jurusan Biologi, Fakultas Matematika dan Ilmu Pengetahuan Alam, Universitas Negeri Semarang, Kampus \\ Sekaran, Gunung Pati, Semarang, Jawa Tengah, Indonesia \\ ${ }^{2)}$ Laboratorium Bioinformatika, Lembaga Biologi Molekuler Eijkman, Jl. Pangeran Diponegoro No. 69 , \\ Jakarta Pusat, Indonesia \\ *)Alamat korespondensi: ikhsannur1996@gmail.com
}

\begin{abstract}
ABSTRAK
Kemajuan teknologi sekuensing menyebabkan peningkatan ketersediaan sekuen genom organisme. Ribuan strain dan isolat dari berbagai populasi organisme telah diisolasi serta diketahui sekuen genomnya. Informasi genetik populasi organisme dapat dimanfaatkan sebagai marka molekuler. Marka Single Nucleotide Polymorphism (SNP) terdapat dalam jumlah banyak namun tidak seluruhnya informatif. Metode seleksi yang telah ada belum efektif menyeleksi SNP informatif, oleh karena itu perlu dilakukan pengembangan metode seleksi SNP yang efektif. Metode seleksi SNP dikembangkan menggunakan metode statistik dengan $F_{\mathrm{ST}}$ sebagai filter (penyaring) utamanya dan digabungkan dengan Linkage Disequilibrium (LD). Struktur populasi dari SNP diketahui menggunakan Principal Component Analysis (PCA), Principal Coordinate Analysis (PCoA), pairwise $F_{\mathrm{ST}}$, dan neighbor-joining population tree. Kriteria SNP informatif diketahui dengan menghitung $F_{\mathrm{ST}}$ dan Minor Allele Frequency (MAF). Metode statistik diuji efektivitasnya dalam menyeleksi SNP informatif menggunakan simulasi data genetik populasi. Hasil penelitian menunjukkan pengembangan metode statistik dengan menggunakan $F_{\mathrm{ST}}$ sebagai penyaring utama efektif dalam menyeleksi SNP informatif. Kriteria SNP informatif adalah SNP dengan MAF 0,2-0,4 serta $F_{\text {ST }}$ 0,1-0,4 dan 0,8-1,0.
\end{abstract}

Kata kunci: data genetik, metode statistik, simulasi, SNP

\section{Statistical Method Simulation for Single Nucleotide Polymorphism Selection}

\author{
${\text { Mohamad Ikhsan Nurulloh }{ }^{1)} \text {, Hidayat Trimarsanto }}^{2)}$, Yustinus Ulung Anggraito ${ }^{1)}$, Endah Peniati ${ }^{1)}, \mathbf{R}$ \\ Susanti $^{1)}$ \\ ${ }^{1)}$ Department of Biology, Faculty of Mathematics and Natural Science, State University of Semarang, \\ Campus of Sekaran, Gunung Pati, Semarang, Central Java, Indonesia \\ ${ }^{2)}$ Bioinformatics Laboratory, Eijkman Institute for Molecular Biology, Jl. Pangeran Diponegoro No. 69 , \\ Central Jakarta, Indonesia \\ ${ }^{*}$ Email: ikhsannur1996@gmail.com
}

\begin{abstract}
The sequencing technology development has led to increase the availability of organisms genome sequences. Thousands of strains and isolates from various populations of organisms have been isolated and known for their genome sequences. Genetic information of organism populations can be used as molecular markers. Single Nucleotide Polymorphism (SNP) markers are present in large numbers but not entirely informative. The existing statistical method has not been effective in selecting informative SNPs, therefore it is necessary to develop an effective SNP selection method. The SNP selection method was developed using $F_{\text {ST }}$ as the main filter and combined with Linkage Disequilibrium (LD). The population structure of SNP is known using Principal Component Analysis (PCA), Principal Coordinate Analysis (PCoA), pairwise $F_{\mathrm{ST}}$, and neighbor-joining population tree. The criteria of informative SNP are known by calculating $F_{\mathrm{ST}}$ and Minor Allele Frequency (MAF). The statistical method was tested for its effectiveness in selecting informative SNP using data simulation of population genetics. The results showed the statistical method was effective in producing informative SNP. The criteria of informative SNP were SNP with MAF 0.2-0.4 and $F_{\text {ST }} 0.1-0.4$ and 0.8-1.0.
\end{abstract}

Keywords: genetic data, statistical method, simulation, SNP 


\section{PENDAHULUAN}

\begin{abstract}
Kemajuan teknologi sekuensing menyebabkan peningkatan ketersediaan sekuen genom organisme. Ribuan strain dan isolat dari berbagai populasi organisme telah diisolasi serta diketahui sekuen genomnya. Informasi genetik populasi organisme dapat dimanfaatkan sebagai marka molekuler.
\end{abstract}

Marka molekuler (molecular marker) merupakan untai DNA yang mengalami variasi dan dapat digunakan untuk mengetahui polimorfisme antar genotipe di dalam populasi. Marka Single Nucleotide Polymorphism (SNP) merupakan marka berdasarkan pada perbedaan satu nukleotida. Marka SNP populer digunakan dalam studi genetika populasi karena tingkat kesalahannya rendah serta lebih banyak analisis populasi yang dapat dilakukan [1].

Lebih dari 10 juta SNP telah diidentifikasi pada genom manusia, rata-rata terdapat satu SNP di setiap 300 nukleotida [2]. Jumlahnya yang banyak tidak seluruhnya informatif akibat kesalahan deteksi, kehadiran sekuen berulang, dan tidak lengkapnya sekuen genom referensi yang menyebabkan keraguan identifikasi SNP. Penggunaan SNP yang tidak informatif akan menghasilkan kesalahan interpretasi populasi. Hal tersebut dapat diatasi dengan seleksi SNP untuk memperoleh SNP informatif.

Seleksi SNP dilakukan menggunakan metode statistika sebagai penyaring (filter) dengan batasan tertentu. Kesalahan penggunaan penyaring berpengaruh terhadap marka yang terseleksi. Misalnya, penggunaan Minor Allele Frequency (MAF) sebagai penyaring dalam seleksi SNP akan menyebabkan bias populasi, yaitu perolehan hasil positif palsu ketika penggunaan SNP dengan nilai MAF terlalu rendah atau tinggi [3]. Metode lainnya seperti Linkage Disequilibrium (LD) belum efektif karena menghasilkan marka SNP dalam jumlah yang banyak [4].

Metode statistik lain seperti $F_{\text {ST }}$ mempunyai potensi untuk dikembangkan sebagai penyaring dalam seleksi SNP. Metode ini berdasarkan pada perbedaan genetik pada dua populasi atau lebih. Berdasarkan penelitian Willing [5] $F_{\text {ST }}$ mampu memberikan informasi struktur populasi dengan jumlah sampel yang sedikit. Metode ini juga digunakan untuk menghitung perbedaan genetik pada data SNP tunggal dan berkelompok [6]. Kajian yang dilakukan Alcala \& Rosenberg [7] membuktikan bahwa $F_{\text {ST }}$ mampu mendeteksi subpopulasi, aliran genetik, sejarah populasi, dan pengaruh demografi terhadap populasi. Studi genetika populasi oleh Lawson [8] menggunakan $F_{\mathrm{ST}}$ untuk identifikasi individu pada populasi campuran (admixture) dan introduksi individu dari luar (outgroup).

Metode statistik untuk seleksi SNP dikembangkan menggunakan $F_{\mathrm{ST}}$ sebagai filter (penyaring) utamanya dan digabungkan dengan Linkage Disequilibrium (LD). Struktur populasi dari SNP diketahui menggunakan Principal Component Analysis (PCA), Principal Coordinate Analysis (PCoA), pairwise $F_{\mathrm{ST}}$, dan neighborjoining population tree. Kriteria SNP informatif diketahui dengan menghitung $F_{\mathrm{ST}}$ dan Minor Allele Frequency (MAF) dari setiap lokus pada data sebelum dan sesudah seleksi SNP.

Metode statistik perlu diuji untuk mengetahui efektivitasnya dalam menyeleksi SNP informatif. Pengujian metode statistik dilakukan dengan simulasi data genetik populasi. Simulasi bertujuan untuk mendapatkan data genetik populasi dengan kondisi yang ditentukan seperti mutasi, rekombinasi, dan migrasi. Metode seleksi SNP dikatakan efektif ketika jumlah SNP yang dibutuhkan untuk identifikasi populasi sedikit dan tidak terdapat perbedaan struktur populasi sebelum dan sesudah seleksi.

\section{METODE PENELITIAN}

Simulasi data genetik populasi. Simulasi dilakukan menggunakan modul simuPOP [9] dengan skenario forward-time. Model ini akan menghasilkan populasi masa depan dengan pengaruh evolusi serta parameter populasi seperti mutasi, migrasi, dan rekombinasi. Populasi awal dibuat dengan 500 individu haploid yang memiliki 500 lokus (450 kromosom dan 50 mitokondria) serta perbandingan genotipe A $(0,2), \mathrm{C}(0,3), \mathrm{T}$ $(0,2)$, dan $\mathrm{G}(0,3)$. Populasi awal dievaluasi dengan melihat hasil genotipe, jumlah lokus, dan jumlah individu serta dikonfirmasi menggunakan PCA dan PCoA. Populasi awal yang terpilih, selanjutnya dievolusi selama 2000 generasi dengan parameter laju mutasi 0,01 , probabilitas rekombinasi 0,001 , dan probabilitas migrasi 0,001 .

Parameter simulasi data genetik populasi diatas memodelkan organisme eukariotik dengan fase hidup dominan haploid. Organisme yang masuk ke dalam golongan tersebut adalah protozoa seperti Plasmodium yang merupakan penyebab penyakit malaria pada manusia. Populasi akhir dipilih ketika telah memenuhi 
kriteria terbentuknya PCA dan PCoA populasi menjadi subpopulasi dan terjadi migrasi.

Seleksi Single Nucleotide Polymorphism (SNP). Metode seleksi SNP dirancang dengan $F_{\mathrm{ST}}$ sebagai penyaring (filter) utamanya. Tahapan seleksi SNP diawali dengan perhitungan $F_{\text {ST }}$ pada tiap lokus. Lokus SNP dengan nilai $F_{\mathrm{ST}}$ nol dihilangkan (seleksi invarian SNP). Selanjutnya SNP dengan nilai $F_{\mathrm{ST}}$ lebih dari nol (varian SNP) diseleksi menggunakan nilai statistik (mean $F_{\mathrm{ST}}$, median $F_{\mathrm{ST}}$, standar deviasi $F_{\mathrm{ST}}$, nilai minimum $F_{\mathrm{ST}}$, dan nilai maksimum $F_{\mathrm{ST}}$ ). Marka dengan jumlah SNP terkecil selanjutnya diseleksi berdasarkan nilainya. Nilai SNP merupakan nilai yang menunjukkan keberadaan lokus SNP pada marka hasil seleksi nilai statistik. Marka dengan jumlah SNP terkecil selanjutnya diseleksi menggunakan agregat $F_{\mathrm{ST}}$, yaitu seleksi berdasarkan penggabungan parameter nilai SNP dan nilai statistik. Tahap selanjutnya SNP dihitung korelasi alelnya (Linkage Disequilibrium) dan lokus dengan nilai LD tinggi dihilangkan. Marka SNP terakhir divisualisasi dengan PCA, PCoA, pairwise $F_{\mathrm{ST}}$, dan neighbor-joining population tree.

Kriteria SNP informatif. Kriteria SNP informatif ditentukan berdasarkan $F_{\mathrm{ST}}$ dan MAF pada data genetik sebelum dan sesudah seleksi. $F_{\text {ST }}$ didapatkan perbandingan rata-rata heterozigositas yang diharapkan dari subpopulasi dengan heterozigositas yang diharapkan dari populasi total sedangkan MAF didapatkan melalui perhitungan frekuensi alel kedua terendah.

\section{HASIL DAN PEMBAHASAN}

Data genetik populasi. Simulasi data genetik populasi telah dilakukan menggunakan skenario forward-time. Model simulasi ini memungkinkan untuk melacak informasi dan sifat populasi pada setiap generasi. Sampel individu dapat diambil dari generasi awal, generasi akhir, dan di setiap generasi. Model ini sangat fleksibel karena dapat untuk mensimulasikan skenario evolusi dengan berbagai pengaruh seperti mutasi, rekombinasi, dan migrasi sehingga sesuai untuk simulasi data genetik populasi yang kompleks [10].
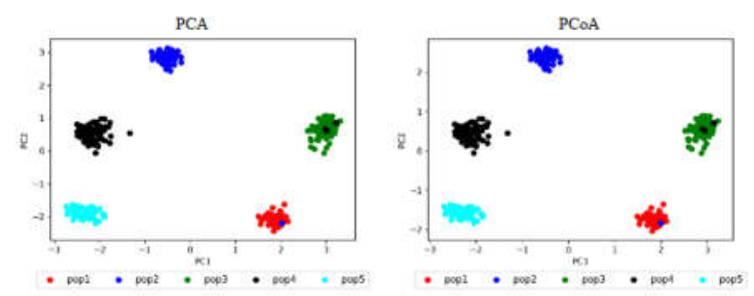

Gambar 1. PCA dan PCoA data genetik populasi generasi ke-1500 (500 individu terbagi dalam lima populasi dengan 500 SNP)

Gambar 1 menunjukkan visualisasi populasi terpilih generasi ke-1500 dengan metode PCA dan PCoA. Kedua metode ini berdasarkan pada jarak genetik individu. Satu titik menggambarkan satu individu dan titik yang warnanya sama menunjukkan bahwa individu-individu tersebut merupakan satu populasi. Populasi telah memisah sempurna menjadi lima populasi baru dan individu pada tiap populasi telah mengelompok. Pada populasi satu dan tiga terdapat titik yang berbada warna. Pada populasi satu (merah) terdapat sebuah titik biru, titik biru (populasi dua) tersebut menunjukkan bahwa individu dari populasi dua mengalami migrasi ke populasi satu. Pada populasi tiga (hijau) terdapat beberapa titik merah (populasi empat), titik merah tersebut menunjukkan bahwa individu pada populasi empat mengalami migrasi ke populasi tiga. Berdasarkan uraian diatas populasi pada generasi ke-1500 telah memenuhi kriteria untuk digunakan sebagai penguji metode seleksi SNP.

Seleksi SNP. Seleksi SNP bertujuan untuk mendapatakan SNP informatif dari jumlahnya yang banyak. Seleksi dilakukan menggunakan kriteria tertentu dengan pengurangan jumlah SNP pada tiap tahap.
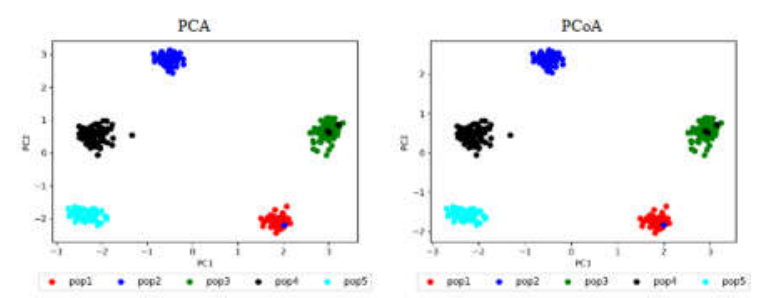

Gambar 2. PCA dan PCoA marka berdasarkan nilai $F_{\mathrm{ST}} /$ varian SNP (224 SNP)

Gambar 2 merupakan visualisasi marka yang diseleksi berdasarkan nilai $F_{\mathrm{ST}}$. Seleksi ini berdasarkan pada penghilangan lokus SNP yang memiliki nilai $F_{\mathrm{ST}}$ nol. Visualisasi populasi menggunakan PCA dan PCoA menunjukkan bahwa tidak terdapat perubahan sebelum seleksi 
(Gambar 1) dan setelah seleksi SNP (Gambar 2 ). Hal tersebut karena SNP dengan nilai $F_{\mathrm{ST}}$ nol tidak mempunyai kontribusi dalam membedakan populasi. Jumlah SNP yang awalnya 500 berkurang hingga 224. Meskipun jumlah SNP berkurang namun masih mampu membedakan populasi dengan tepat.
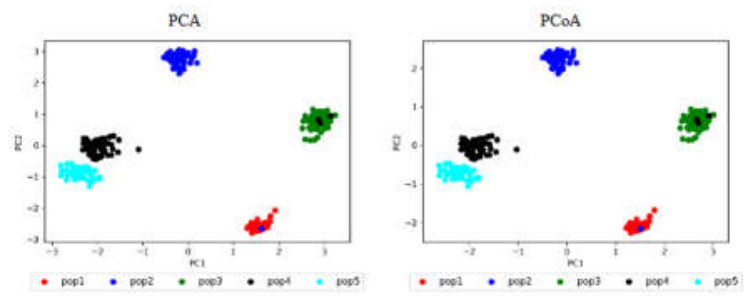

Gambar 3. PCA dan PCoA marka nilai statistik (60 SNP)
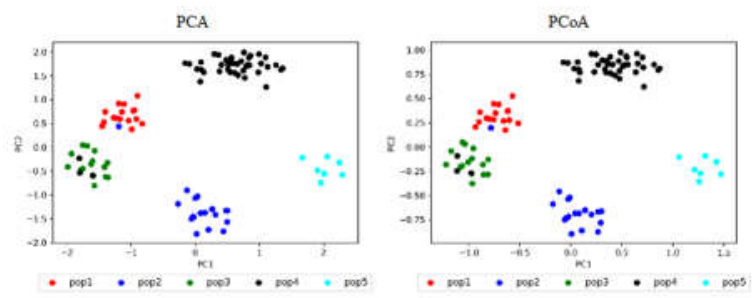

Gambar 4. PCA dan PCoA marka nilai SNP (25 SNP)
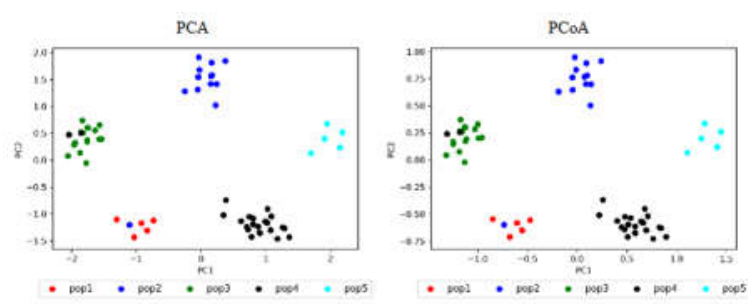

Gambar 5. PCA dan PCoA marka agregat $F_{\mathrm{ST}}$ (25 SNP)

Visualisasi marka secara berturut turut ditunjukan pada Gambar 3, Gambar 4, dan Gambar 5. Berdasarkan visualisasi tersebut marka yang diseleksi berdasarkan nilai statistik (60 SNP), nilai SNP (25 SNP), dan agregat $F_{\mathrm{ST}}$ (25 SNP) menyebabkan perubahan posisi populasi namun tidak menyebabkan perubahan struktur populasi (titik-titik PCA dan PCoA bergabung).

Lokus SNP pada marka yang telah diperoleh dari agregat $F_{\mathrm{ST}}$ diseleksi menggunakan Linkage Disequilibrium (LD). Metode ini berdasarkan pada asosiasi non-acak dari alel-alel yang memungkinkan untuk diturunkannya sepasang alel secara bersamaan sehingga dapat digunakan salah satu alel saja sebagai marka.

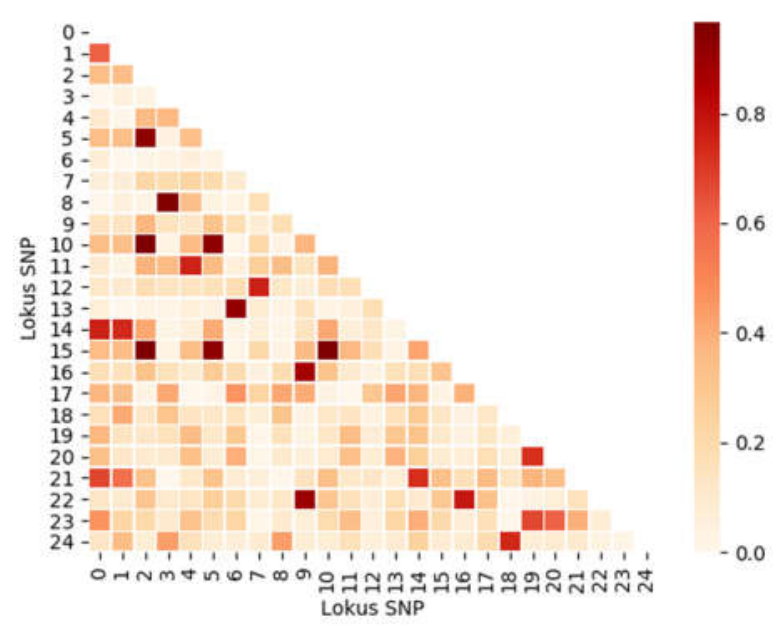

Gambar 6. Heat map korelasi lokus LD $\left(r^{2}\right)$ marka agregat $F_{\text {ST }}$

Korelasi lokus LD pada Gambar 6 menunjukkan terdapat beberapa lokus SNP dengan nilai LD tinggi (warna merah tua). Lokus SNP dikurangi hingga hasil PCA dan PCoA tidak memisah. Berdasarkan hasil PCA dan PCoA jumlah lokus SNP yang dapat dikurangi adalah lima (Gambar 7). Pengurangan enam lokus SNP akan menyebabkan perubahan struktur populasi (hasil PCA dan PCoA bergabung) (Gambar 8).
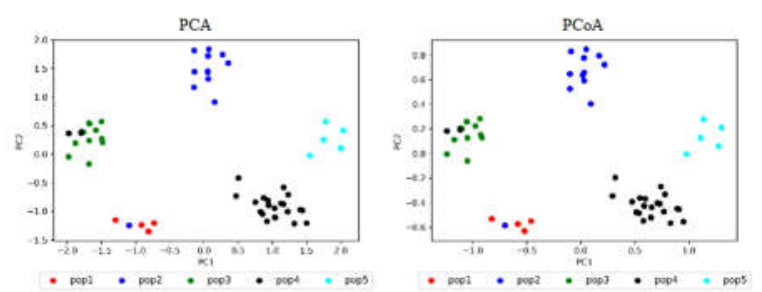

Gambar 7. PCA dan PCoA marka LD (marka akhir) dengan 20 SNP
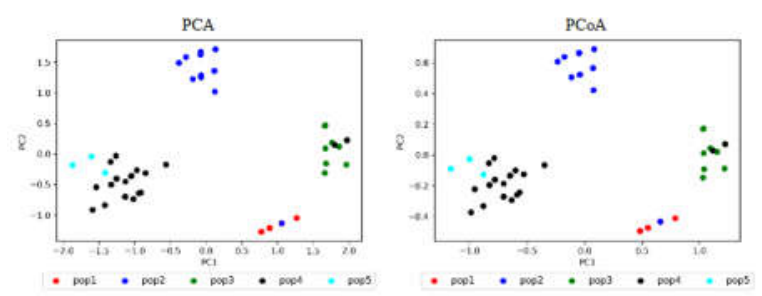

Gambar 8. PCA dan PCoA marka LD (19 SNP)

Jumlah akhir lokus SNP setelah pengurangan adalah 20. Struktur populasi sebelum dan sesudah seleksi tidak berubah hal itu ditunjukkan pada hasil PCA dan PCoA (Gambar 1 dan Gambar 7). Metode seleksi SNP efektif karena tidak menyebabkan perubahan struktur populasi dan memerlukan sedikit SNP untuk identifikasi populasi. 


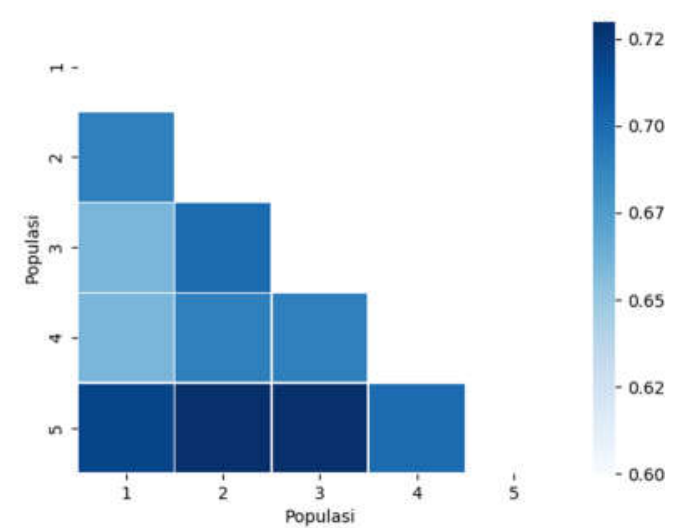

Gambar 9. Heat map pairwise $F_{\mathrm{ST}}$ data simulasi

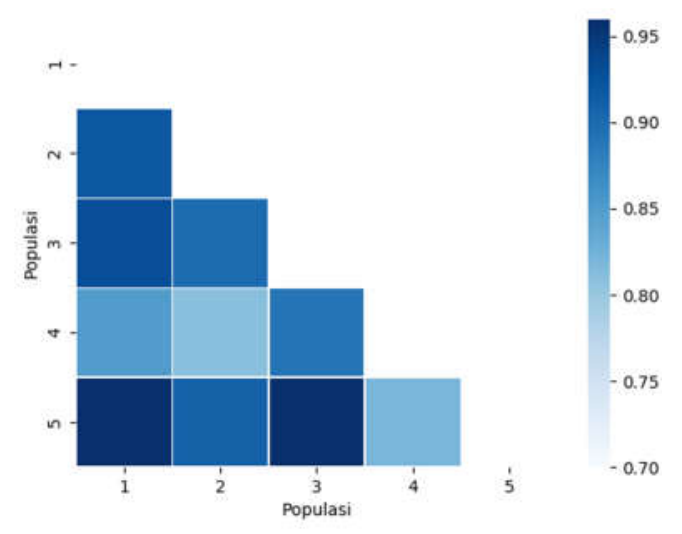

Gambar 10. Heat map pairwise $F_{\mathrm{ST}}$ seleksi

Gambar 9 dan Gambar 10 menunjukkan nilai $F_{\text {ST }}$ berpasangan dari populasi satu hingga lima. Warna pada heat map yang semakin biru menunjukkan nilainya semakin tinggi. Nilai pairwise $F_{\mathrm{ST}}$ data simulasi populasi (Gambar 9) berada direntang 0,60-0,72 sedangkan pairwise $F_{\mathrm{ST}}$ data seleksi (Gambar 10) berada direntang 0,70-0,95. Hal tersebut menunjukkan peningkatan nilai pairwise $F_{\mathrm{ST}}$ antar populasi sebelum dan sesudah seleksi SNP. Nilai $F_{\text {ST }}$ yang tinggi menunjukkan jika SNP yang diperoleh lebih informatif untuk membedakan populasi.

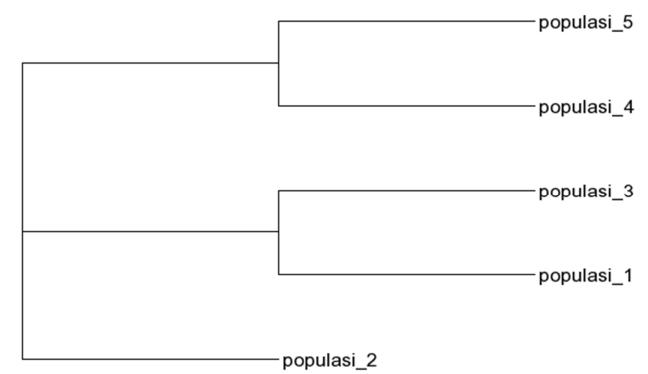

Gambar 11. Neighbor-joining population tree marka akhir
Neighbor-joining population tree (Gambar 11) mengambarkan hubungan antar populasi. Populasi yang simulasi populasi dan sebelum sesudah seleksi SNP. Setelah dilakukan Seleksi SNP dari 500 hingga tersisa 20 SNP tetap menghasilkan neighbor-joining population tree yang sama.

$F_{\text {ST }}$ sebagai filter (penyaring) utama dalam menyeleksi SNP mempunyai peran yang penting. Umumnya $F_{\mathrm{ST}}$ digunakan untuk mengetahui perbedaan genetik diantara dua atau lebih populasi. Nilai $F_{\text {ST }}$ yang tinggi menunjukkan bahwa populasi tersebut jauh kekerabatannya begitu juga sebaliknya. $F_{\mathrm{ST}}$ dalam seleksi SNP berfungsi untuk mengetahui kontribusi sebuah lokus SNP dalam populasi. Beberapa lokus akan memiliki nilai $F_{\text {ST }}$ yang tinggi pada populasi tertentu sedangkan lokus lainnya akan memiliki nilai $F_{\mathrm{ST}}$ yang rendah. Lokus SNP dengan nilai $F_{\text {ST }}$ rendah memiliki kontribusi sedikit dalam membedakan populasi sehingga lokus tersebut dapat dihilangkan.

Visualisasi dari data genetik dilakukan menggunakan PCA, PCoA dan neighbor-joining tree. Visualisasi memberikan informasi mengenai pengaruh mutasi, rekombinasi, dan migrasi terhadap struktur populasi. Visualisasi juga menggambarkan pengaruh pengurangan SNP terhadap sturuktur populasi. Metode PCA sesuai digunakan untuk proses visualisasi data dengan cepat namun memiliki kekurangan terhadap data yang hilang. Metode PCoA memberikan alternatif bagi PCA karena metode ini berdasarkan data jarak (similarity dan disimiliarity) sehingga data yang hilang dapat diperkirakan nilainya. Data genetik yang sama ketika divisualisasikan dengan metode PCA dan PCoA seharusnya akan menghasilkan grafik yang berbeda namun akan menghasilkan grafik yang sama ketika keanekaragaman individu di dalam populasi rendah. Neighbor-joining tree memberikan konfirmasi mengenai struktur populasi yaitu kekerabatan diantara populasi.

Seleksi SNP berdasarkan Linkage Disequilibrium (LD) menggunakan prisip adanya asosiasi antar alel yang memungkinkan untuk dilakukan penggunaan salah satu alel pada pasangan alel yang mempunyai nilai LD tinggi. Metode ini sangat efisien digunakan untuk menghilangkan efek multikolinearitas yaitu kelebihan penaksiran SNP informatif akibat dari banyaknya SNP yang saling berkorelasi [11]. Pengurangan lokus dengan LD yang rendah akan menyebabkan populasi bercampur. Hal tersebut menunjukkan pasangan alel dengan LD rendah 
memiliki asosiasi rendah dan berkontribusi besar sebagai pembeda populasi.

Kriteria SNP informatif. $F_{\text {ST }}$ marka akhir berada pada kisaran tinggi dan rendah. Secara umum, nilai $F_{\text {Sт }}$ tinggi menunjukkan tingkat alel bersama yang rendah (alel privat) antara individu dalam populasi sampel dan total populasi. Alel privat merupakan alel berfrekuensi besar dengan variasi yang rendah, umumnya ditemukan hanya dalam satu populasi. Sebaliknya, nilai $F_{\mathrm{ST}}$ rendah menunjukkan bahwa anggota subpopulasi berbagi alel dengan total populasi. Proporsi individu dalam populasi yang membawa alel tertentu (alel privat) bervariasi dari waktu ke waktu dan dipengaruhi oleh migrasi, penyimpangan genetik, dan seleksi alam. Sebenarnya SNP dengan $F_{\text {ST }}$ tinggi dapat digunakan sebagai marka, namun dibeberapa kasus pada populasi dengan tingkat kemiripan yang sangat tinggi diperlukan SNP dengan nilai $F_{\mathrm{ST}}$ yang rendah untuk memastikan individu masuk ke populasi tersebut. Hal tersebut sesuai dengan penelitian oleh Aykanat [12] yang menunjukkan $F_{\mathrm{ST}}$ dengan nilai rendah juga memiliki peran dalam membedakan populasi. Gambar 12 menunjukkan $F_{\mathrm{ST}}$ tiap lokus marka varian SNP berada direntang 0,01 hingga 1 sedangkan, marka akhir mempunyai dominan SNP dengan rentang $F_{\mathrm{ST}} 0,8-1,0$ dan $0,1-0,4$.

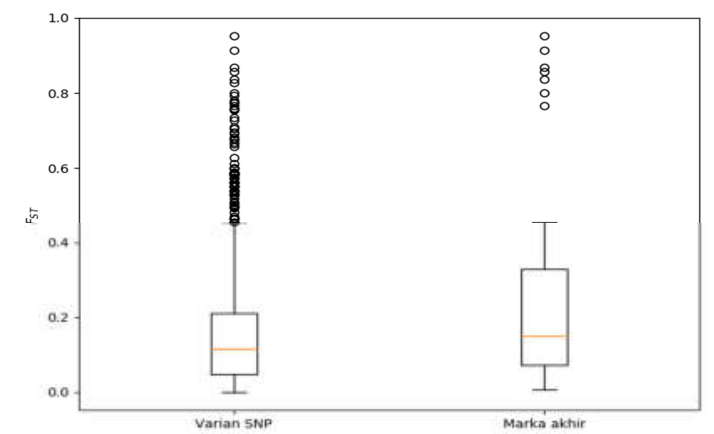

Gambar 12. Boxplot $F_{\mathrm{ST}}$ marka varian SNP (224 SNP) dan marka akhir (20 SNP).

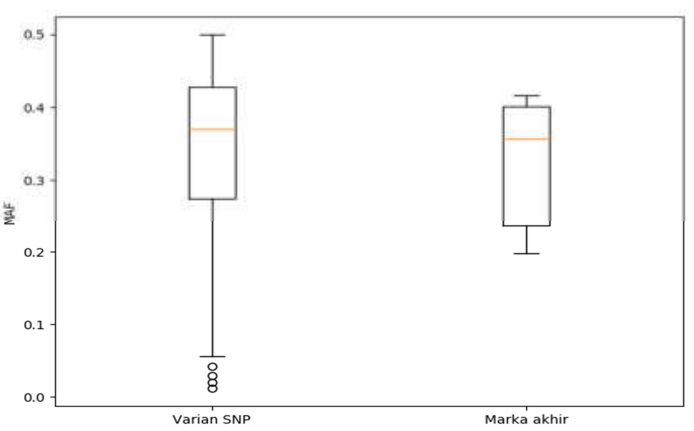

Gambar 13. Boxplot MAF marka varian SNP (224 SNP) dan marka akhir (20 $\mathrm{SNP})$

Gambar 13 menunjukkan MAF marka akhir berada pada rentang 0,2-0,4 sedangkan MAF kandidat marka varian SNP berada pada rentang 0,01-0,5. Marka SNP sebagai pembeda populasi memiliki kisaran MAF yang tidak terlalu rendah dan tinggi. MAF informatif berada di MAF 0,20,4 . Hasil ini sesuai dengan penelitian oleh De la Cruz \& Raska [13] yang menyatakan bahwa MAF untuk SNP informatif berada pada kisaran 0,2-0,4. SNP dengan MAF 0,4-0,5 akan kehilangan kemampuan untuk membedakan populasi. Lokus SNP dengan MAF rendah menunjukkan bahwa lokusnya mendapatkan kontribusi alel dari populasi lain sedangkan SNP dengan MAF yang tinggi menunjukkan alelnya memberi kontribusi ke populasi lain. Penggunaan SNP dengan MAF terlalu tinggi dan rendah dapat menyebabkan kesalahan dalam interpretasi populasi akibat pengaruh kontribusi alel atau bias dalam pengamatan, yaitu perolehan hasil positif palsu ketika penggunaan SNP dengan MAF rendah [3].

Nilai MAF dan $F_{\text {ST }}$ dipengaruhi oleh banyaknya sampel dan populasi yang akan dianalisis. Nilai MAF akan tinggi ketika jumlah populasi sedikit. Sedangkan $F_{\mathrm{ST}}$ dipengaruhi oleh banyaknya sampel di tiap populasi. Populasi dengan alel yang beragam akan menyebabkan nilai $F_{\mathrm{ST}}$ rendah sedangkan jika alelnya seragam (alel privat) dan hanya terdapat di populasi tersebut maka $F_{\text {ST }}$ tinggi. Alel dengan frekuensi yang tinggi akan mempengaruhi $F_{\mathrm{ST}}[14]$.

Keterbatasan penelitian. Simulasi data genetik populasi dalam penelitian ini memiliki beberapa batasan. Pertama, tidak terjadi seleksi sehingga jumlah populasi dari tiap generasi sama. Kedua, tidak terjadi introduksi gen asing dari luar sehingga proses evolusi lama. Metode yang dilakukan memiliki batasan karena menggunakan $F_{\mathrm{ST}}$, populasi dengan struktur genetik yang kemiripannya tinggi memerlukan lebih banyak 
SNP informatif agar tidak terjadi bias populasi. Hal ini dapat diatasi dengan melakukan pairwise $F_{\text {ST }}$ populasi agar diketahui minimal jumlah SNP yang dibutuhkan.

\section{KESIMPULAN}

Pengembangan metode statistik dengan menggunakan $F_{\text {ST }}$ sebagai penyaring utama efektif dalam menyeleksi SNP informatif. Kriteria SNP informatif adalah SNP dengan MAF 0,2-0,4 serta $F_{\text {ST }} 0,1-0,4$ dan 0,8-1,0.

\section{DAFTAR PUSTAKA}

[1] Kaiser SA, Taylor SA, Chen N, Sillett TS, Bondra ER, Webster MS (2017) A Comparative assessment of SNP and microsatellite markers for assigning parentage in a socially monogamous bird. Molecular Ecology Resources 17 (2): 183-193. doi: 10.1111/17550998.12589 .

[2] Liu Z, Liu J, Wang J, Chen D, Liu Z, Shi J, Li Z, Li W, Zhang G, Du B (2018) A Set of 14 DIP-SNP markers to detect unbalanced DNA mixtures. Biochemical and Biophysical Research Communications 497 (2): 591-596. doi: 10.1016/j.bbrc.2018.02.109.

[3] Linck EB, Battey CJ (2017) Minor allele frequency thresholds strongly affect population structure inference with genomic datasets. bioRxiv 1 (1): 1-26. doi: $10.1101 / 188623$.

[4] Fu W, Dekkers J, Lee WR, Abasht B (2015) Linkage disequilibrium in crossbred and pure line chickens. Genetics Selection Evolution 47 (1): 1123. doi: 10.1186/s12711-015-0098-4.

[5] Willing E-M, Dreyer C, van Oosterhout $C$ (2012) Estimates of genetic differentiation measured by $F_{\mathrm{ST}}$ do not necessarily require large sample sizes when using many SNP markers. PLoS ONE 7 (8): 42649-42656. doi: 10.1371/journal.pone.0042649.

[6] Bhatia G, Patterson N, Sankararaman S, Price AL (2013) Estimating and interpreting $F_{\mathrm{ST}}$ : The impact of rare variants. Genome Research 23 (9): 1514-1521. doi:
[7] Alcala N, Rosenberg NA (2017) Mathematical constraints on $F_{\mathrm{ST}}$ : Biallelic markers in arbitrarily many populations. Genetics 206 (3): 1581-1600. doi: 10.1534/genetics.116.199141.

[8] Lawson DJ, van Dorp L, Falush D (2018) A Tutorial on how not to over-interpret structure and admixture plots. Nature Communications 9 (1): 3258-3269. doi: 10.1038/s41467-018-05257-7.

[9] Peng B, Kimmel M, Amos CI (2012) Forward-time population genetics simulations: Methods, implementation, and applications. Wiley-Blackwell, Canada. doi: 10.1002/9781118180358

[10] Peng B, Chen H-S, Mechanic LE, Racine B, Clarke J, Gillanders E, Feuer EJ (2015) Genetic data simulators and their applications: An overview. Genetic Epidemiology 39 (1): 2-10. doi: 10.1002/gepi.21876.

[11] Wittenburg D, Teuscher F, Klosa J, Reinsch N (2016) Covariance between genotypic effects and its use for genomic inference in half-sib families. G3 Genes Genomes Genetics 6 (9): 2761-2772. doi: 10.1534/g3.116.032409.

[12] Aykanat T, Johnston SE, Orell P, Niemelä E, Erkinaro J, Primmer CR (2015) Low but significant genetic differentiation underlies biologically meaningful phenotypic divergence in a large atlantic salmon population. Molecular Ecology 24 (20): 5158-5174. doi: 10.1111/mec.13383.

[13] De la Cruz O, Raska P (2014) Population structure at different minor allele frequency levels. BMC Proceedings 8 (1): 55-60. doi: 10.1186/1753-6561-8-S1-S55.

[14] Jakobsson M, Edge MD, Rosenberg NA (2013) The relationship between $F_{\mathrm{ST}}$ and the frequency of the most frequent allele. Genetics 193 (2): 515-528. doi: 10.1534/genetics.112.144758. 